\title{
The Guadalfeo Monitoring Network (Sierra Nevada, Spain): 14 years of measurements to understand the complexity of snow dynamics in semiarid regions
}

\author{
María J. Polo, Javier Herrero, Rafael Pimentel, and María J. Pérez-Palazón \\ Fluvial Dynamics and Hydrology Research Group - Andalusian Institute for Earth System Research (IISTA), \\ University of Cordoba, Córdoba, 14071, Spain \\ Correspondence: María J. Polo (mjpolo@uco.es)
}

Received: 30 September 2018 - Discussion started: 12 November 2018

Revised: 25 February 2019 - Accepted: 4 March 2019 - Published: 19 March 2019

\begin{abstract}
This work presents the Guadalfeo Monitoring Network in Sierra Nevada (Spain), a snow monitoring network in the Guadalfeo Experimental Catchment, a semiarid area in southern Europe representative of snowpacks with highly variable dynamics on both annual and seasonal scales and significant topographic gradients. The network includes weather stations that cover the high mountain area in the catchment and time-lapse cameras to capture the variability of the ablation phases on different spatial scales. The data sets consist of continuous meteorological high-frequency records at five automatic weather stations located at different altitudes ranging from 1300 to $2600 \mathrm{~m}$ a.s.l. that include precipitation, air temperature, wind speed, air relative humidity and the short- and longwave components of the incoming radiation, dating from 2004 for the oldest station (2510 m a.s.1.) (https://doi.org/10.1594/PANGAEA.895236); additionally, daily data sets of the imagery from two time-lapse cameras are presented, with different scene area $(30 \mathrm{~m} \times 30 \mathrm{~m}$, and $2 \mathrm{~km}^{2}$, respectively) and spatial resolution, that consist of fractional snow cover area and snow depth from 2009 (https://doi.org/10.1594/PANGAEA.871706) and snow cover maps for selected dates from 2011 (https://doi.org/10.1594/PANGAEA.898374). Some research applications of these data sets are also included to highlight the value of high-resolution data sources to improve the understanding of snow processes and distribution in highly variable environments. The data sets are available from different open-source sites and provide both the snow hydrology scientific community and other research fields, such as terrestrial ecology, riverine ecosystems or water quality in high mountains, with valuable information of high potential in snow-dominated areas in semiarid regions.
\end{abstract}

1

Warming trends in climate cause an alarming change in snow patterns over mountainous areas (Liston and Hiemstra, 2011). The dominant role of snowfall over these areas is being shifted to a rainfall-snowfall regime, which changes the snow accumulation dynamics (Musselman et al., 2017). Evaposublimation and snowmelt have also altered their behaviour, with a clear impact on the hydrological response and changes in both the timing and availability of water resources. Taking into account that one-sixth of the total Earth's population depends on snowmelt for water resources, i.e. hydropower production, drinking water and irrigation (Barnett et al., 2005), these areas require a particular scientific focus. Great efforts have been taken in mountain hydrology in large mountainous ranges (Mankin and Diffenbaugh, 2015; Mernild et al., 2017), specifically the world's major mountain ranges (Marty et al., 2017; Verbyla et al., 2017; Rizzi et al., 2018). However, there are a significant number of mountainous areas situated in warmer and drier midlatitudes, where snowmelt also constitutes the main component of the total water resources during the summer season. This is the case of semiarid Mediterranean mountainous areas (Fayad et al., 2017), for instance, Sierra Nevada (south- 
ern Spain; Perez-Palazón et al., 2018), the eastern part of the Pyrenees (Spain; López-Moreno et al., 2009), the Atlas mountain range (northern Morocco; Marchane et al., 2015), Mount Etna and the southern Calabrian mountains (Italy; Senatore et al., 2011), the southern face of the Alps (France and Italy), the Taurus Mountains (Turkey), Mount Lebanon and the Anti-Lebanon Mountains (Lebanon; Mhawej et al., 2014), Sierra Nevada (USA; Molotch and Meromy, 2014), and the Andes (Chile; Favier et al., 2009; Váldés-Pineda et al., 2014). Moreover, the majority of them comprise spots or areas with high environmental value, in many cases biosphere reserves with an outstanding amount of endemism. Thus, these regions also constitute natural laboratories where warming trends are not only being noticed but also have significant impacts on the snow dynamics. Consequently, they are locations where these effects can be evaluated early, provided the availability of key observations to analyse the major drivers of change (López-Moreno et al., 2017). A large number of current studies are focused on reproducing the most likely future climate scenarios and their impacts and trying to establish strategies to adapt to and mitigate these changes (Andrew and Sauquet, 2017; Ergon et al., 2018). However, the intrinsic variability of climate and the large spatial coverage of the snowpack in these areas, with frequently patchy behaviour, not only at the end of the snow season, but also during the autumn and winter due to the different accumulation-ablation cycles, in Mediterranean mountain regions pose an opportunity to study the impact of the climate trends on snow occurrence and persistence and to anticipate likely changes in higher latitudes.

Snow distribution in warm mid- and low-latitude locations is more variable and irregular than in northern regions. (1) Several accumulation-melting cycles occur throughout the year, with very different duration (Pimentel et al., 2017c). (2) A wide range of snow depth states is usually found, generally closer to the order of magnitude of the surrounding microrelief (1-1000 mm) (Anderton et al., 2004). (3) A particular patchy snow distribution, ranging from $1 \mathrm{~m}^{2}$ to hundreds of square metres (Pimentel et al., 2017a), is one of the major consequences of extremely variable conditions over these regions (i.e. high level of solar radiation between precipitation events, mild winters followed by cool springs and vice versa and the alternance of severe drought periods and highly torrential wet seasons). All these variability sources make an accurate, continuous and well distributed monitoring network necessary that is able to capture the main processes related to snow dynamics, both meteorological forcing and snow properties, and ultimately their impact on the river flow. However, the difficult access to mountainous areas complicates the installation and maintenance of meteorological stations and somehow limits continuous surveys and field campaigns being carried out in practice to monitor the snow properties. Hence, there is usually a lack of weather stations in high mountain areas, which increases in semiarid regions since monitoring efforts are concentrated in the agricultural areas in mid-latitudes and low altitudes.

Sierra Nevada (Spain) is a clear example of a high mountain area in a semiarid context. This $80 \mathrm{~km}$ long mountain range runs parallel to the shoreline of the Mediterranean Sea in southern Spain, with frequent snowfall from November to April in the area above $2000 \mathrm{~m}$ a.s.l. that usually undergoes much ablation before the summer. Its proximity to the sea favours the coexistence of Mediterranean and alpine climates within just a $40 \mathrm{~km}$ distance. Its particular location and steep topographic gradient make Sierra Nevada a region recognized as one of the most important reservoirs of biodiversity in Europe, with the presence of a large number of endemic species (Heywood, 1995; Blanca, 2002; Anderson et al., 2011), as well as being a major ski resort in southern Europe during the spring. The projections of future climate in this area (Pérez-Palazón et al., 2018) point out the enhancement of the variability of the snowfall regime and the increased frequency of ablation cycles during the season. However, the weather network was restricted to the area below $1500 \mathrm{~m}$ a.s.l. until the beginning of the 21 st century, mostly concentrated below $1000 \mathrm{~m}$ a.s.l., and a significant gap was found to not only estimate snowfall but also analyse temperature and precipitation regimes in the mountains. The southern face of Sierra Nevada is the headwater area of the Guadalfeo River basin and constitutes the major water source for urban supply and high-value crop irrigation in the coastal areas downstream, where there is a big reservoir, built in 2002, to face drought periods and the increasing development of coastal tourism and related facilities.

This work presents the monitoring network implemented in Sierra Nevada since 2004 to study the snow dynamics in this area and its hydrological impacts. The Guadalfeo Monitoring Network comprises five automatic weather stations located above $1300 \mathrm{~m}$ a.s.l., mainly in the Guadalfeo River basin, that were gradually installed during 2004-2017; additionally, three time-lapse cameras complement the network and provide high-resolution images of the snow cover area on different spatial scales from 2009. The Guadalfeo Network has been developed and maintained since then by the Fluvial Dynamics and Hydrology Research Group from the Andalusian Institute for Earth System Research. The data set included consists of a 13-year series of weather variables (2004-2018), a 7-year series of snow observations from terrestrial imagery (2009-2016) and a number of snow cover maps from a second camera on selected dates (during 2011-2013), from which snow modelling (Herrero et al., 2009, 2011), weather variables' analysis and mapping (Aguilar et al., 2010; Aguilar and Polo, 2011; Herrero and Polo, 2012), snowmelt-evaposublimation partitioning (Herrero and Polo, 2016), subgrid-scale effects of patchy snow conditions (Pimentel et al., 2015, 2017c) and other snowrelated processes or impacts have been studied (Millares et al., 2009, 2014; Gómez-Beas et al., 2012; Gómez-Giráldez et 
al., 2014; Egüen et al., 2016; Pimentel et al., 2017a; LópezMoreno et al., 2017; Algarra et al., 2019).

\section{The Guadalfeo River basin}

The Guadalfeo River basin is one of the five main watersheds whose headwaters belong to the Sierra Nevada mountain range in southern Spain (Fig. 1). Its location on the southwestern face of Sierra Nevada results in a predominant southern orientation, with high insolation rates during the year and a proximity to the Mediterranean Sea, which makes this watershed a very particular environment due to the coexistence of a Mediterranean climate in the lower elevations and an alpine climate in the headwaters of the catchment. This main south-facing aspect changes in the western zones, as the higher hillsides are north-oriented. Low-population areas and marginal agriculture (supported by snowmelt-fed historical irrigation systems) are found in the mountains, whereas the coast and the bottom valley are densely populated, with the local economy based on tropical-crop-growing and tourism. The highest area of the catchment (above 1000-1500 m a.s.l.) is included in the Sierra Nevada National Park, which is also a biosphere reserve. There are two reservoirs in the watershed: Béznar $\left(56 \mathrm{hm}^{3}\right.$ maximum capacity) and Rules $\left(111 \mathrm{hm}^{3}\right.$ maximum capacity). The first one is located in the Ízbor River, a tributary of the Guadalfeo River, whose flow comes from the north-oriented area within the catchment, and the second one is located in the Guadalfeo River main stream and collects water from the whole southern face and the outflow from the Béznar reservoir. Additionally, small dams for hydropower generation are present upstream of the reservoirs in the snow-dominated areas in the mountains. The location of Rules dam is selected as the output of the watershed, since the flow regime is modified downstream and the available records cannot then be used to reproduce the natural fluvial regime; moreover, the daily inflow data to the reservoir are used for the closure of the water and energy balance on the catchment scale.

The Guadalfeo Experimental Catchment comprises the contributing area to the Rules dam, a control point of inflow to the reservoir. This upstream catchment has an area of $1058 \mathrm{~km}^{2}$, with an average elevation of $1418 \mathrm{~m}$ a.s.l, ranging from 300 to $3479 \mathrm{~m}$ a.s.l. The average annual precipitation is very variable, even in consecutive years, and ranges from approximately 300 to $1200 \mathrm{~mm}$ in dry and wet years, respectively. The average daily temperature in the Guadalfeo basin for the last 40 years was $12.4^{\circ} \mathrm{C}$ (Pérez-Palazón et al., 2015), which is higher than values recorded in other alpine climates with similar altitudes. These average values are calculated over a reference period (1690-2000) with all meteorological information available in the catchment for this period (red and black dots in Fig. 2). The vegetation in the snowdominated area, mainly above $2000 \mathrm{~m}$ a.s.l., is composed of pastures and low shrubs (Hormathophylla spinosa, Genista versicolor and Festuca Clementei). Some isolated spots of reforested conifers can also be found in this area but never in elevations higher than $2500 \mathrm{~m}$ a.s.1. In contrast, outside of the snow area, small oak, poplar and chestnut tree forests and traditional agriculture are the dominant areas.

The monitoring resources in the Guadalfeo Experimental Catchment consist of the Guadalfeo Network (Fig. 2), whose weather and camera stations are mostly located in this catchment, all of them above $1200 \mathrm{~m}$ a.s.l.; other weather station networks operated by public national and regional agencies (mostly below $1000 \mathrm{~m}$ a.s.l.); the Refugio Poqueira experimental site (surrounding area of PG2 in Fig. 2) at $2500 \mathrm{~m}$ a.s.l., where snow and soil are monitored by additional instrumentation and systematic field campaigns for snow monitoring are carried out; and gauge stations in the main streams and inflow estimations to the reservoirs, both operated by the River Basin District of the Andalusian Mediterranean Basins.

\section{The Guadalfeo Network}

The Guadalfeo Network was specifically designed to both fill the gap in the weather station distribution above $1000 \mathrm{~m}$ a.s.l. in Sierra Nevada and monitor the weather and snow regime in the snow-dominated areas. Figure 2 shows the location of the automated weather stations (PG points) and camera locations for terrestrial imagery acquisition, including their respective associated scenes, together with the reservoirs and gauge stations in the river network. The weather stations have been sequentially installed since 2004 and they are equipped to monitor the radiation components. The following points describe the network in detail.

\subsection{Weather stations}

Five weather stations are currently included in the Guadalfeo Network (red dots in Fig. 2). Table 1 and Fig. 3 show, respectively, the equipment installed at each station and the chronological sequence of the network development and data acquisition. Three domains can be identified in the stations' distribution:

- PG1 (November 2005) and PG2 (November 2004) are the highest stations of the network (around $2500 \mathrm{~m}$ a.s.1.); they are located in two of the main headwater subbasins within the catchment, in the Bérchules and Poqueira valleys, respectively. PG4 (October 2012) is also located in the Poqueira River subbasin at a lower elevation than PG2 to capture the altitudinal gradient, which is particularly important in this valley due to the steepness of the terrain.

- PG3 (August 2009) is located outside of the Sierra Nevada mountain range, in the left margin of the Guadalfeo River in the Contraviesa Mountains, exactly 


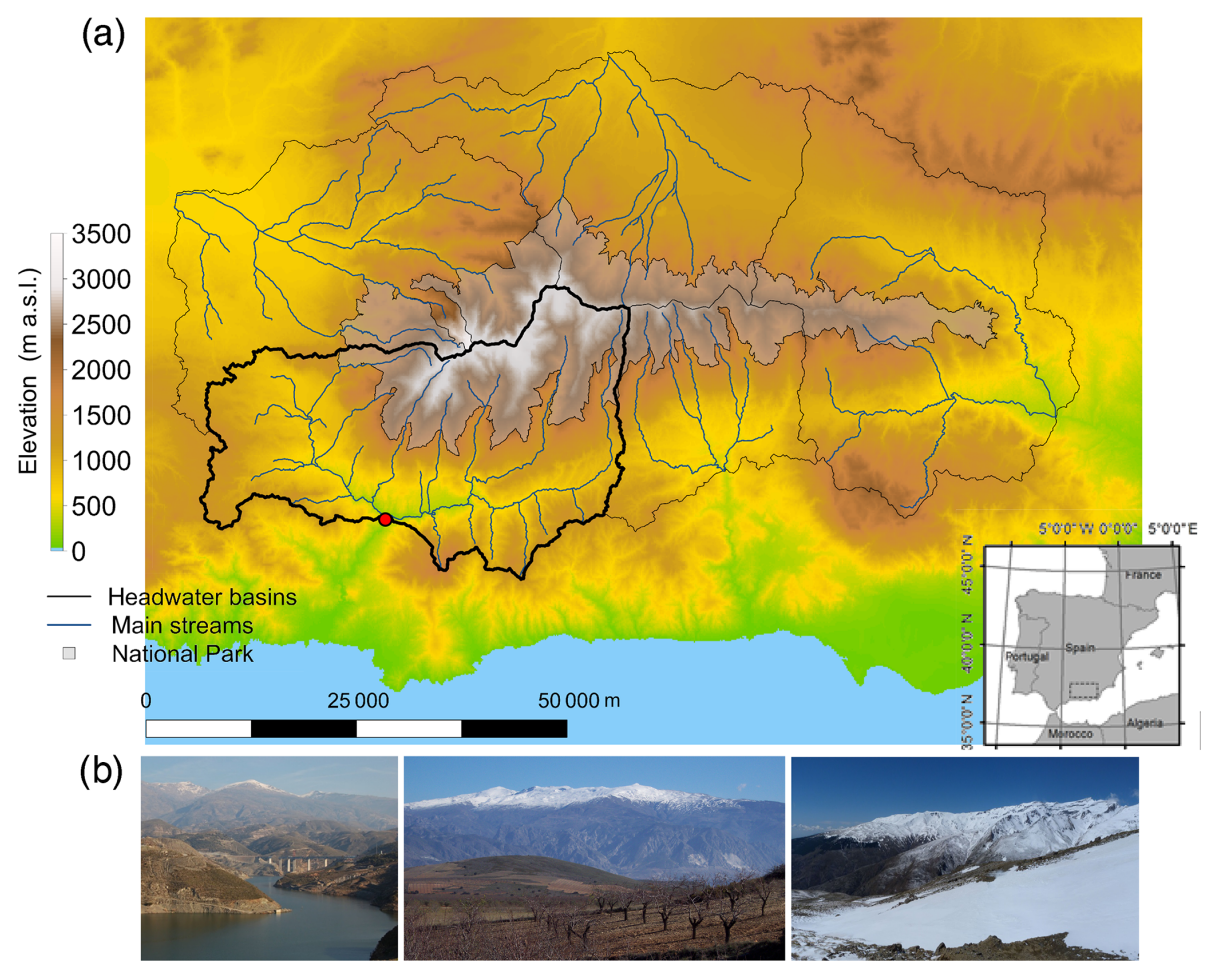

Figure 1. The Guadalfeo Experimental Catchment study site in Sierra Nevada (Spain). (a) Topography of the area, major fluvial streams and limits of the catchment (black line); the red circle corresponds to the Rules dam, the closure of the catchment, and the greyish area is the National Park domain. The inset shows the location in Spain. (b) Some representative views.

in the crest of the range; this area lacked stations to capture the altitudinal gradients of the meteorological variables, and this point was needed to improve the precipitation distribution and, thus, the hydrological modelling of the inflows to the Rules reservoir, which also receives runoff from this area. Moreover, sea influence is also relevant on this location.

- Finally, PG5 (March 2017) is so far the only station in the network that is located outside of the Guadalfeo Experimental Catchment; its location was chosen as a first step to fill the gap of meteorological information in the north-western area of Sierra Nevada.

All the stations monitor six weather variables: precipitation, temperature, relative humidity of the air, incoming shortwave radiation (not measured by PG1), wind and atmospheric pressure (Table 1). The incoming longwave radiation is additionally measured at PG2, PG3 and PG5. At each station, a data logger records $5 \mathrm{~min}$ averages of $5 \mathrm{~s} \mathrm{sam}-$ pling rate observations; data are transmitted via modem to the Andalusian Institute for Earth System Research, where they undergo a quality-control process. This quality control consists of standard limit checking, intercomparison of values for each variable with the nearby stations and internal checking of the values of a given variable in the context of the whole set of information at the same station (including video images). As a result, any suspicious $5 \mathrm{~min}$ record is removed from the series; to generate hourly series, only periods with fewer than two removals are kept (i.e. a maximum uncertainty of $8.33 \%$ is due to gaps in the record), and only days with complete hourly values are included in the daily series. No gap filling is done on the resulting series on any timescale to keep the original data set, and it is up to the user to apply any gap-filling technique if required. Additionally, periodic calibration of the solar radiation, temperature and relative humidity sensors is performed on an annual basis by means of portable calibrated sensors provisionally installed beside each station. The fraction of removed records varies depending on the variable but is generally below $0.01 \%$ in the network.

No correction is done on the data to account for potential snow undercatch; the pluviometers above $1500 \mathrm{~m}$ a.s.l. are equipped with either Alter or Tretyakov shields to improve snow catching; the different field tests performed at the stations sites showed negligible undercatch amounts during the most frequent events. The mean value of wind speed during snowfall events ranges between 3.1 and $4.8 \mathrm{~m} \mathrm{~s}^{-1}$ at stations PG1 to PG4 (with mode values ranging from 1 to $2.5 \mathrm{~m} \mathrm{~s}^{-1}$ ) and $0.8 \mathrm{~m} \mathrm{~s}^{-1}$ at station PG5 (with a mode value of $1 \mathrm{~m} \mathrm{~s}^{-1}$ ). However, under extreme conditions this might not hold; during the study period the maximum wind speed registered ranged from $12.1 \mathrm{~m} \mathrm{~s}^{-1}$ (PG3) and $24.7 \mathrm{~m} \mathrm{~s}^{-1}$ (PG1). 


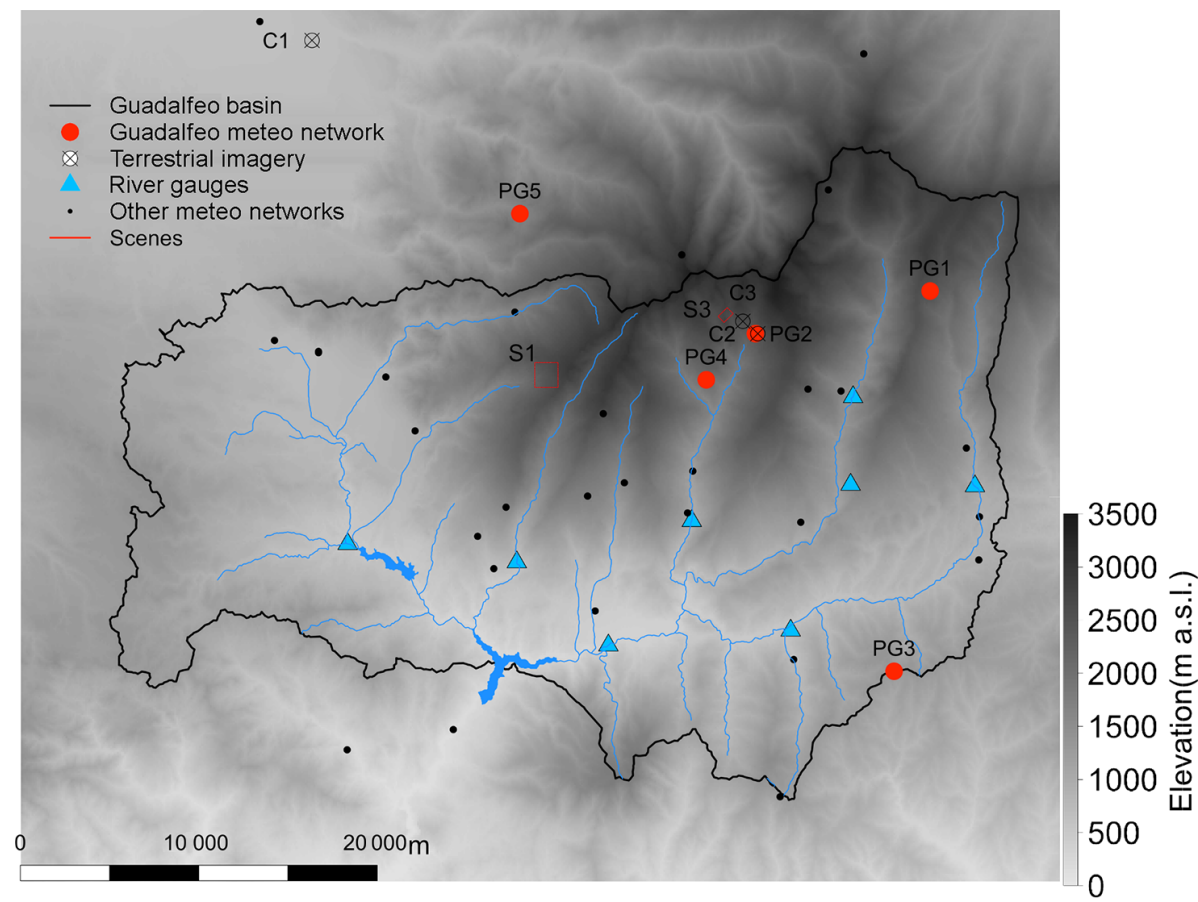

Figure 2. The Guadalfeo Network in Sierra Nevada (Spain). PG, weather stations (red circles); C, time-lapse cameras (crossed circles); S, the camera scenes (red rectangles; S2 is a near-field scene and cannot be represented due to its size). Black points identify the location of weather stations belonging to other meteorological networks in the Sierra Nevada area. The limits of the Guadalfeo Experimental Catchment (black line), the main river streams (blue line), gauge stations (blue triangles) and reservoirs (blue areas) are included over the elevation map of the area.

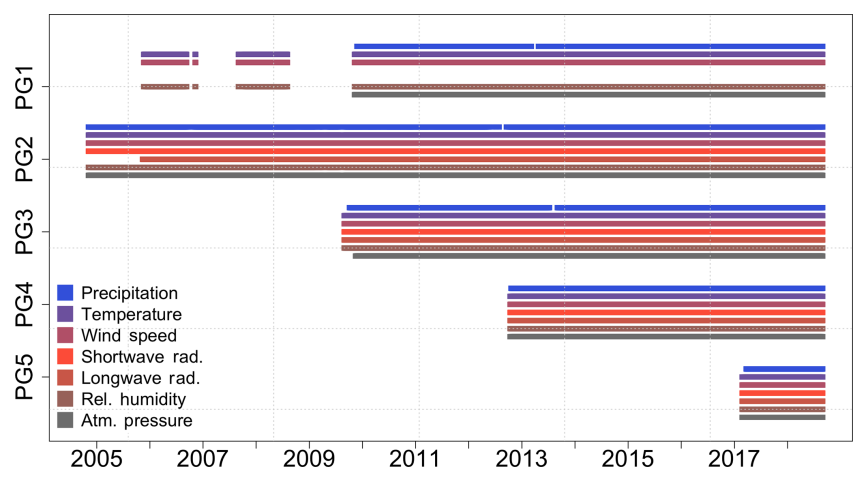

Figure 3. Recording period and data availability for each weather station and variable in the Guadalfeo Network (Sierra Nevada, Spain) since 2004.

Again, the data are delivered without any modification so that interested users can decide whether they are correct or not for their own applications, provided that the wind data are also included in the data set.

With very few exceptions, the stations have been recording data on a continuous basis since their deployment; PG1 had some initial problems and was reinstalled at the end of summer 2009 (Fig. 3).

\subsection{Terrestrial imagery}

Currently, the Guadalfeo Network includes three time-lapse cameras (Fig. 2), all located above $1200 \mathrm{~m}$ a.s.l., which cover different scenes associated with different spatial scales. Table 2 shows selected characteristics of each camera together with an example image to illustrate the scene they capture. Two of them (C2 and C3) are both located and cover a scene in the highest region of the Guadalfeo Experimental Catchment but with different spatial scale and resolution.

$\mathrm{C} 2$, at the Refugio Poqueira experimental site in the surroundings of PG2, covers a $30 \mathrm{~m} \times 30 \mathrm{~m}$ scene (equivalent to the spatial resolution of the Landsat TM sensors) and is devoted to the microscale effects on snow ablation; it also complements the information recorded by the weather station, since it provides sub-daily measurements of snow depth (by means of calibrated rods easy to identify from the images) and estimations of snow-covered area in the scene (after processing of the images).

C3 covers a larger scene $(500 \mathrm{~m} \times 500 \mathrm{~m})$ and provides sub-daily estimations of snow cover area on the hillslope scale, as a validation data source for the results from $\mathrm{C} 2$.

Finally, $\mathrm{C} 1$ is focused over a larger hillslope in the only subbasin of the Guadalfeo Experimental Catchment on the northern face of Sierra Nevada; this camera covers the largest scene $\left(2 \mathrm{~km}^{2}\right)$ in the network, and the images provide both 
Table 1. Main characteristics of the weather stations in the Guadalfeo Network: elevation (ma.s.1.), date of installation and instruments. In situ pictures are also shown.

\begin{tabular}{|c|c|c|c|c|c|}
\hline & $8=4$ & $=\frac{}{7}$ & $\frac{2}{6 a^{2}}$ & 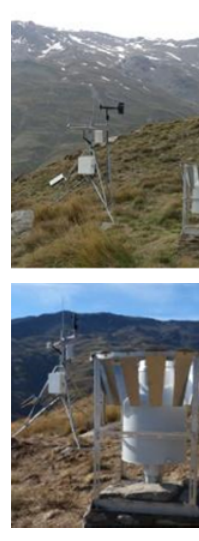 & 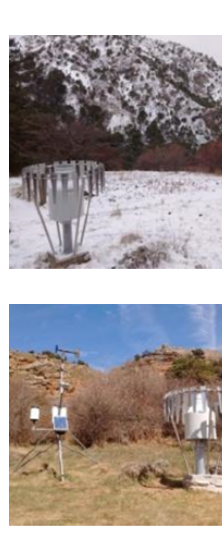 \\
\hline ID & PG1 & PG2 & PG3 & PG4 & PG5 \\
\hline Elevation & 2470 & 2510 & 1332 & 2141 & 1675 \\
\hline Installation & $\begin{array}{l}\text { Nov } 2005 \\
\text { operational }\end{array}$ & $\begin{array}{l}\text { Nov } 2004 \\
\text { operational }\end{array}$ & $\begin{array}{l}\text { Aug } 2009 \\
\text { operational }\end{array}$ & $\begin{array}{l}\text { Oct } 2012 \\
\text { operational }\end{array}$ & $\begin{array}{l}\text { Mar } 2017 \\
\text { operational }\end{array}$ \\
\hline Rain gauge & OTT Pluvio 2 & Geonor T-200B & Young 52203 & OTT Pluvio 2 & $\begin{array}{l}\text { OTT Pluvio } 2 \text { \& } \\
\text { Young } 52203\end{array}$ \\
\hline $\begin{array}{l}\text { Temperature } \\
\text { Relative } \\
\text { humidity }\end{array}$ & $\begin{array}{l}\text { Campbell Scientific } \\
\text { CS215 }\end{array}$ & $\begin{array}{l}\text { Vaisala } \\
\text { HMP45C }\end{array}$ & $\begin{array}{l}\text { Vaisala } \\
\text { HMP45C }\end{array}$ & $\begin{array}{l}\text { Vaisala } \\
\text { HMP45C }\end{array}$ & $\begin{array}{l}\text { Campbell } \\
\text { CS HC2S3 }\end{array}$ \\
\hline Pyranometer & - & $\begin{array}{l}\text { Kipp \& Zonnen } \\
\text { SP Lite }\end{array}$ & $\begin{array}{l}\text { Hukseflux } \\
\text { LP02-05 }\end{array}$ & $\begin{array}{l}\text { Hukseflux } \\
\text { LP02-05 }\end{array}$ & $\begin{array}{l}\text { Hukseflux } \\
\text { LP02-05 }\end{array}$ \\
\hline Pyrgeometer & - & $\begin{array}{l}\text { Kipp \& Zonen } \\
\text { CGR3 }\end{array}$ & $\begin{array}{l}\text { Hukseflux } \\
\text { IR02 }\end{array}$ & $\begin{array}{l}\text { Hukseflux } \\
\text { IR02 }\end{array}$ & $\begin{array}{l}\text { Hukseflux } \\
\text { IR02 }\end{array}$ \\
\hline $\begin{array}{l}\text { Alpine Wind } \\
\text { Monitor }\end{array}$ & $\begin{array}{l}\text { Young } \\
05103-45\end{array}$ & $\begin{array}{l}\text { Young } \\
05103-45\end{array}$ & $\begin{array}{l}\text { Young } \\
05103-45\end{array}$ & $\begin{array}{l}\text { Young } \\
05103-45\end{array}$ & $\begin{array}{l}\text { Young } \\
05103-45\end{array}$ \\
\hline Barometer & $\begin{array}{l}\text { CS100, } \\
\text { Setra } 278\end{array}$ & $\begin{array}{l}\text { Druck } \\
\text { RPT410F }\end{array}$ & $\begin{array}{l}\text { CS100, } \\
\text { Setra } 278\end{array}$ & $\begin{array}{l}\text { CS100, } \\
\text { Setra } 278\end{array}$ & $\begin{array}{l}\text { CS100, } \\
\text { Setra } 278\end{array}$ \\
\hline
\end{tabular}

monitoring of the snow cover area evolution on this area and ground-truth data for the validation of and/or filling of the snow cover area maps from satellite sources.

The terrestrial images are processed in a two-step methodology: georeferencing and colour detection. Georeferencing uses a digital elevation model (DEM) to provide the image with spatial coordinates by means of a standard automatic computer vision algorithm (Foley, 1996; Fiume, 2014). Secondly, for the detection of snow pixels, a clustering $K$ means algorithm is applied (MacQueen, 1967) that classifies the pixels in the image into two clusters: snow-covered and snow-free pixels (Pimentel et al., 2015); finally, the snow cover area in the image is calculated by aggregation of pixels in each cluster. Additionally, the snow depth, $h$, was obtained in each image using the red-painted poles installed in the scene area and using the same clustering algorithm to deter- mine pole and no-pole pixels in a predefined search window that isolates the poles in the images (Pimentel et al., 2015, 2017a). The accuracy of the observations from the camera data was estimated to be $0.075 \mathrm{~m}^{2} \mathrm{~m}^{-2}$ for the snow cover fraction (SCF) and $50 \mathrm{~mm}$ for the height of snow (HS). The associated error for SCF is due to the combined effects of both the georeferencing process and the snow detection algorithm; the former depends on the relationship between the number of pixels in the images and the resolution of the local DEM, and the latter is related to the accuracy of the $K$-means algorithm used. In the case of HS, the error depends on the position of the rods installed in the control area and also on the accuracy of the clustering algorithm used. 
Table 2. Main characteristics of the time-lapse cameras in the Guadalfeo Network: elevation (ma.s.1.), date of installation, instruments, frequency and spatial resolution. In situ pictures of both their locations and scenes are also shown. Dates are provided as yyyy/mm/dd.

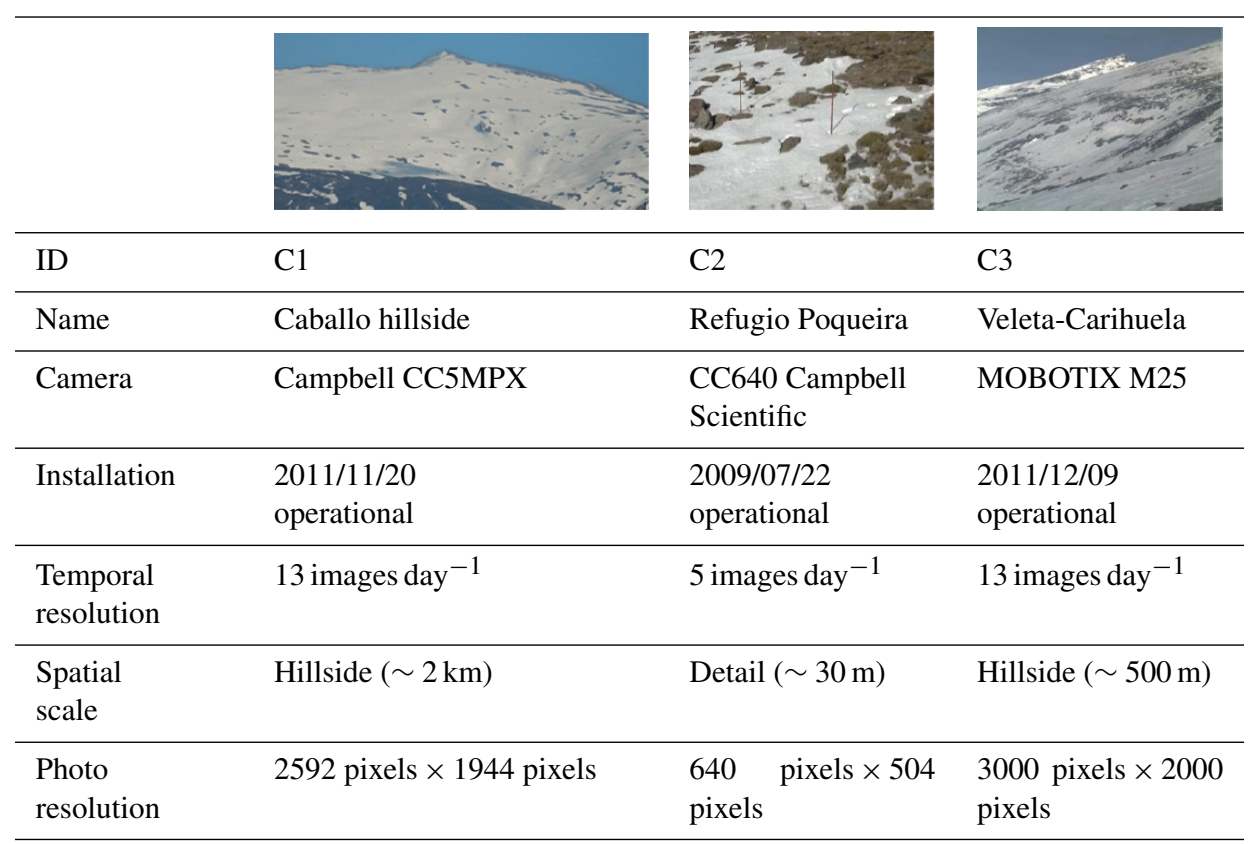

\section{Data description}

\subsection{Meteorological data from the weather stations}

Figure 4 shows the temporal evolution of the meteorological data registered in each station of the Guadalfeo Network during the period 2004-2017 on an annual basis, together with their seasonal distribution within the year by means of their monthly descriptor during the monitoring period at each site. The different graphs illustrate relevant features of the climate regime in high mountain areas in semiarid regions, as expressed in the Introduction: (i) the high variability of the precipitation and temperature regimes on different timescales and the seasonality of the precipitation pattern; (ii) the larger temperature interval on a local basis, due to the spring and summer periods, much warmer than other snow domains in higher latitudes; (iii) the importance of the radiation components, with higher amounts of incoming radiation on an annual level, especially during spring-summer periods; and (iv) the influence of the proximity to the sea, with air relative humidity annual intervals rather stable during the study period for a given station.

The distribution of the different stations in the network allows some spatial comparison, despite the different duration of the time series at each site (Fig. 3). PG5 is the only station on the northern face of Sierra Nevada, and it only has 1 year of records; PG1, PG2, and PG4 are located on the southern face, and PG3 is on the southern water divide of the Guadalfeo River basin (outside of the snow-dominated area in the watershed). PG2-PG4 trace a north-south gradient in the same valley, whereas PG2-PG1 trace a west-east gradient along the same altitudinal line (Fig. 2); their respective annual temperature intervals and descriptors mainly reflect the altitude level within the Sierra Nevada range, and the mean monthly descriptors show the clear seasonal pattern in this latitude.

Regarding the precipitation regime, PG2-PG4 show the maximum altitudinal band on the southern face around 1900-2200 m a.s.l., already identified in other works (PérezPalazón et al., 2018) and the decline of precipitation along the west-east axis (PG2-PG1) associated with the major trajectories of the Atlantic cyclonic fronts in this region. Autumn and late winter-early spring are the seasons during which most of the precipitation is concentrated, November and March being the most variable months; very scarce precipitation is found from June to August at all sites.

Wind speed can reach high values during the snow season in the snow domain sites (PG1, PG2, PG4), which has a clear impact on evaposublimation rates and snow redistribution in these areas (Herrero and Polo, 2016).

The local incoming radiation components reflect the annual evolution of the solar cycle, with the minimum solar activity reported during 2007-2009 and a minimum around January 2009 (NOAA, 2016), which corresponds with the annual incoming shortwave radiation in 2008-2009 in Fig. 4 (1 September 2008-31 August 2009); the incoming longwave radiation also shows this regime to be 1 order of magnitude lower than the shortwave component on an annual basis. The altitudinal gradient among the different stations can also be observed from the annual values of both components: the shortwave annual value increases with height on 




Figure 4. Annual and monthly descriptors of the meteorological variables monitored during 2004-2017 by each weather station in the Guadalfeo Network. Column (a) shows annual precipitation, annual mean daily temperature, annual mean daily wind speed, annual incoming short- and longwave radiation and annual mean air relative humidity. Column (b) shows mean monthly precipitation, temperature, wind speed, incoming short- and longwave radiation and air relative humidity. Box plots show the median values (black line), the interval range and the 10th and 90th percentiles (whiskers) of each sample (series duration in Fig. 3).

the southern face of Sierra Nevada (PG4-PG2), and PG3 and PG5 show the influence of their location (southern position in the network and northern face of Sierra Nevada, respectively), whereas the longwave annual value reflects the different temperature range, as expected. The seasonal distribution follows a clear pattern during the year, with minimum values in December and February for the short- and longwave components, respectively, as expected.

Finally, the air humidity annual values show the influence of the semiarid context of this mountain range, with inter- vals range larger than those usually found in snow domains in higher latitudes; both the precipitation regime and vicinity to the sea influence the local values found at each site. The seasonal pattern also reflects the seasonal pattern of precipitation, with local maximum values and the largest variability being mainly concentrated in autumn and late winterearly spring; extremely dry conditions in July can also be observed. 
Table 3. Selected statistical annual descriptors of the daily fractional snow cover (FSC) and height of snow (HS) during the snow season (1 November-31 May) in the C2 scene at the Refugio Poqueira experimental site in the Guadalfeo Experimental Catchment (located by PG2, 2510 m a.s.l.; Fig. 2). SD refers to standard deviation.

\begin{tabular}{lrrrr|rrrrr}
\hline & \multicolumn{4}{c|}{ FSC (\%) } & \multicolumn{4}{c}{ HS (mm) } \\
\cline { 2 - 9 } & mean & mode & median & SD & mean & mode & median & SD \\
\hline $2009-2010$ & 0.54 & 0 & 0.68 & 0.43 & 220 & 0 & 82 & 291 \\
$2010-2011$ & 0.62 & 1 & 0.99 & 0.45 & 375 & 0 & 341 & 367 \\
$2011-2012$ & 0.23 & 0 & 0.00 & 0.33 & 42 & 0 & 0 & 81 \\
$2012-2013$ & 0.42 & 0 & 0.35 & 0.42 & 129 & 0 & 11 & 191 \\
$2013-2014$ & 0.28 & 0 & 0.18 & 0.33 & 33 & 0 & 0 & 66 \\
$2014-2015$ & 0.44 & 0 & 0.41 & 0.42 & 80 & 0 & 0 & 110 \\
$2015-2016$ & 0.19 & 0 & 0.00 & 0.31 & 30 & 0 & 0 & 74 \\
Total & 0.41 & 0 & 0.29 & 0.42 & 140 & 0 & 11 & 239 \\
\hline
\end{tabular}

\subsection{Snowpack variables from terrestrial imagery}

Figure 5 shows selected images from $\mathrm{C} 1$ and $\mathrm{C} 2$ cameras in the Guadalfeo Network during the period 2009-2016, together with the resulting snow maps in each scene for different dates.

As described in Sect. 3, C2 is implemented in the experimental site in Refugio Poqueira, and the $30 \mathrm{~m} \times 30 \mathrm{~m}$ scene it covers corresponds to the surrounding area of the weather station PG2 at $2510 \mathrm{~m}$ a.s.l. This is the longest time series of images in the network, and its spatial resolution and scale allows snow depth to be monitored. The 7-year time series of both fractional snow cover (FSC) in the scene area and snow depth on a daily basis is represented in Fig. 6 for each year in this period, and Table 3 includes some statistical annual descriptors of both variables during the snow season (1 November-31 May).

The results clearly show the extremely high variability of the snow cover fraction in this site and the relevance of the ablation processes during the snow season, with null values for the mode of FSC and snow depth all the years, with the exception of 2010-2011, which exhibited a deep and persistent snowpack during the season (Fig. 6). The variation coefficient ranges between 0.73 and 1.63 around a global value of 1 for the study period, being lower or close to 1 for the years with longer persistence of the snowpack in the site and higher than 1 for lower persistence conditions.

The snow depth shows a higher variability, with variation coefficient values ranging between 0.98 and 2.47 around a global value of 1.71 for the study period and the same pattern described for FSC.

2009-2010 and 2010-2011 are representative years of persistent snowpacks from autumn to spring, even though several phases of complete ablation took place during the snow season. On the other hand, other years show a clear predominance of snow-free periods. This annual variability results in highly significant differences in the annual snowmelt fraction (and volume) feeding aquifers and surface waters. (a)

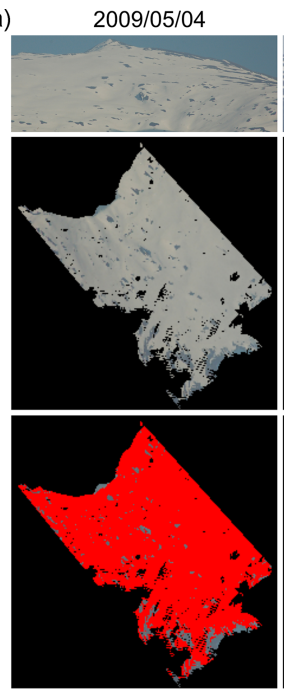

(b)

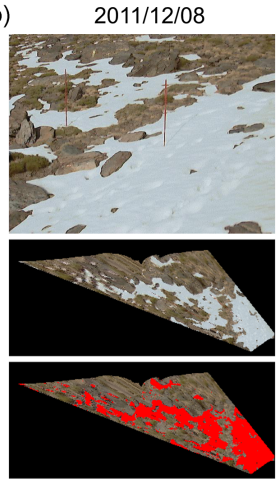

$2013 / 06 / 16$

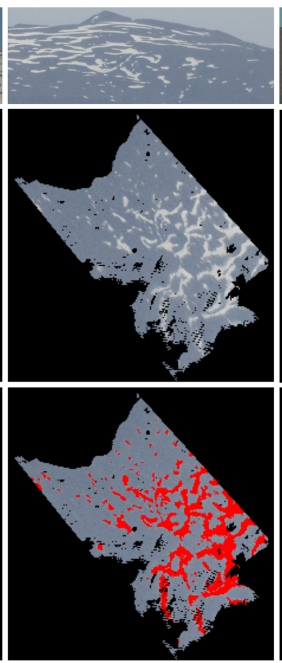

$2013 / 01 / 20$

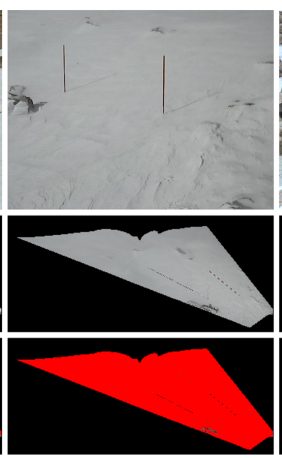

$2010 / 07 / 18$

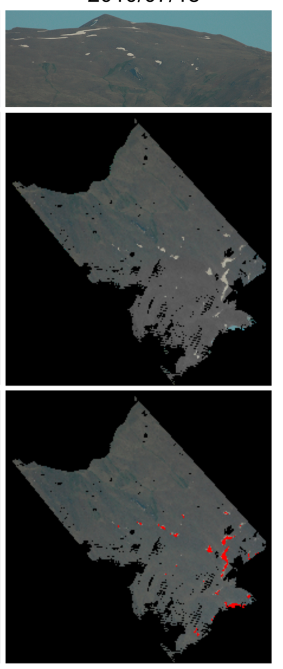

$2012 / 05 / 03$

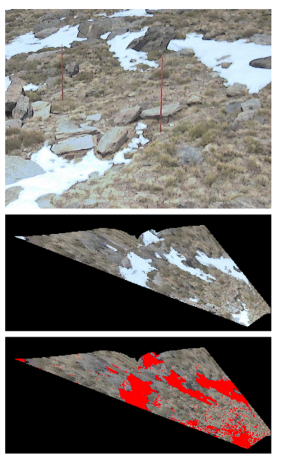

Figure 5. Selected examples of the images, georeferenced projections and snow maps (red pixels) from the time-lapse cameras (a) $\mathrm{C} 1\left(2 \mathrm{~km}^{2}\right)$ and (b) $\mathrm{C} 2(30 \mathrm{~m} \times 30 \mathrm{~m})$ in the Guadalfeo Network that illustrate the patchy pattern of the spatial distribution of the snow in the study site.

On the other hand, in the study period, three different years are found with scarcity of snow: 2011-2012, 2013-2014 and 2015-2016, with similar orders of magnitude for both FSC 

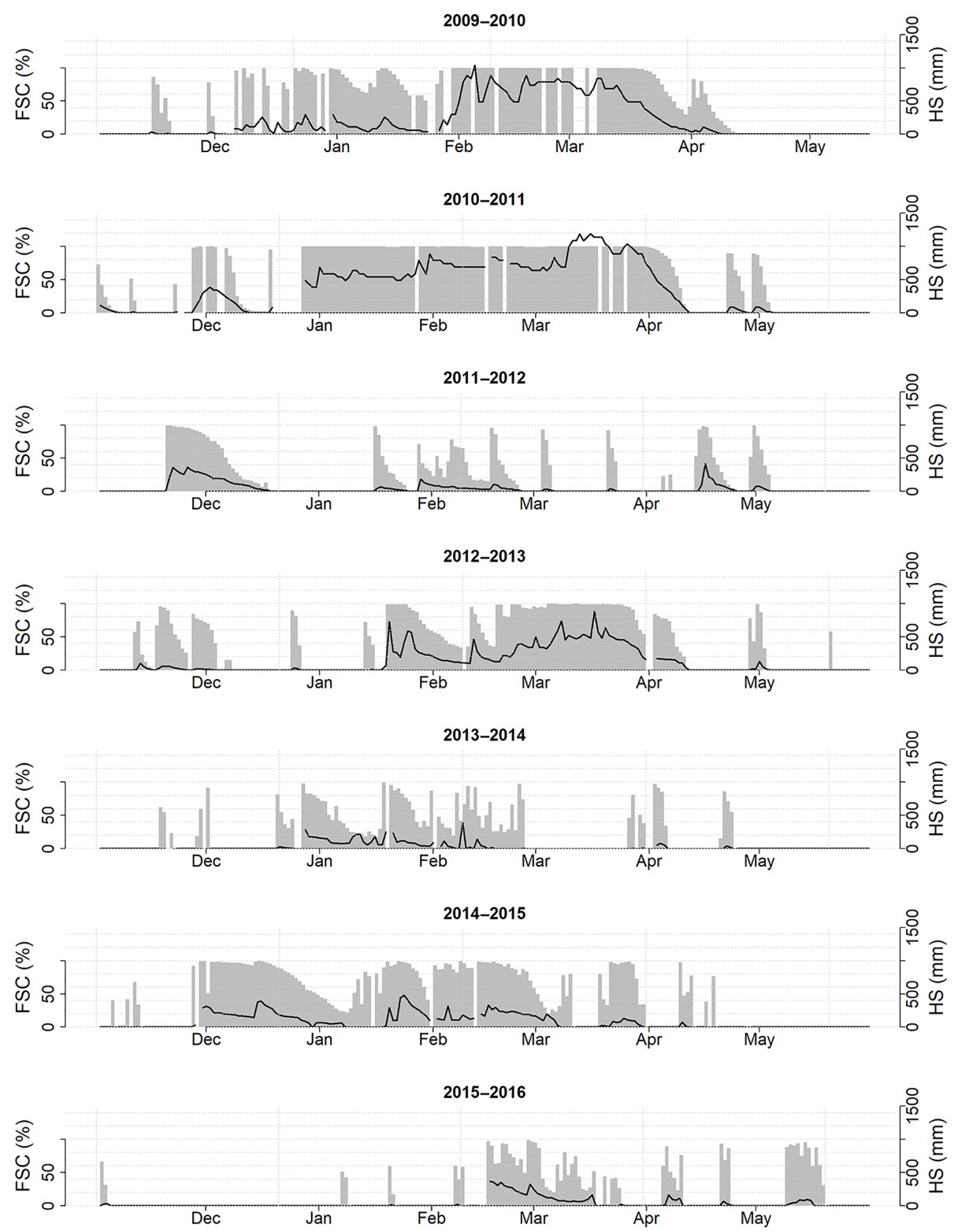

Figure 6. Snow variables retrieved from the images of the time-lapse camera C2 in the Guadalfeo Network. Evolution of the observed daily fractional snow cover (FSC) and height of snow (HS) from the $30 \mathrm{~m} \times 30 \mathrm{~m}$ scene during the snow season (1 November-31 May) during each hydrological year of the period 2009-2016.

and snow depth on an annual basis. However, significant differences are found in their respective seasonal patterns of snow persistence. From Fig. 6, it can be easily observed that autumn, winter and late winter-early spring, respectively, are the snow persistence seasons in each of these three years, whereas the highest number of days without snow in this site are concentrated in winter, spring and autumn, respectively. This seasonal variability has an expected impact on the pattern of the ablation phases (Pimentel et al., 2017c) and the timing of the peak flows of snowmelt but also on the partitioning of snowmelt-evaposublimation fluxes from the snowpack (Herrero and Polo, 2016) that finally deter- mines the available water volume input to the water systems in the basin and the fluvial recession flows (Aguilar and Polo, 2016).

\subsection{Data applications for research and operational capabilities}

The presented data have been used in different research works on the snow dynamics in Mediterranean regions and as input data sources to operational applications of these results. Figure 7 shows the importance of snowfall at each station in the Guadalfeo Monitoring Network on both an annual and 
(a) $\square$ Precipitation
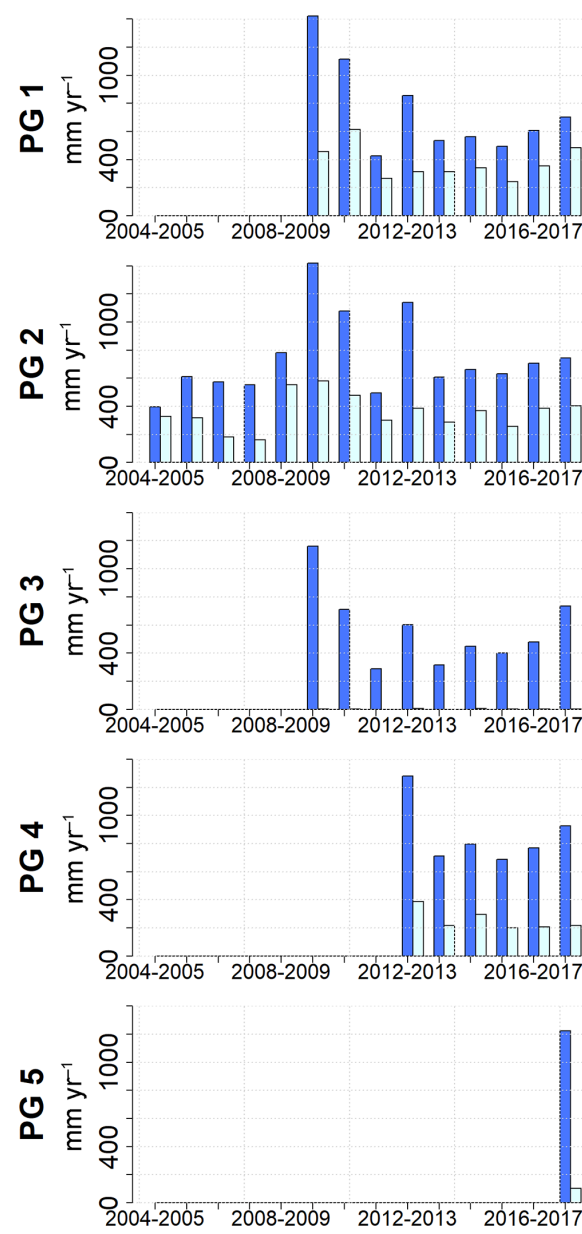

(b) $\square$ Snowfall
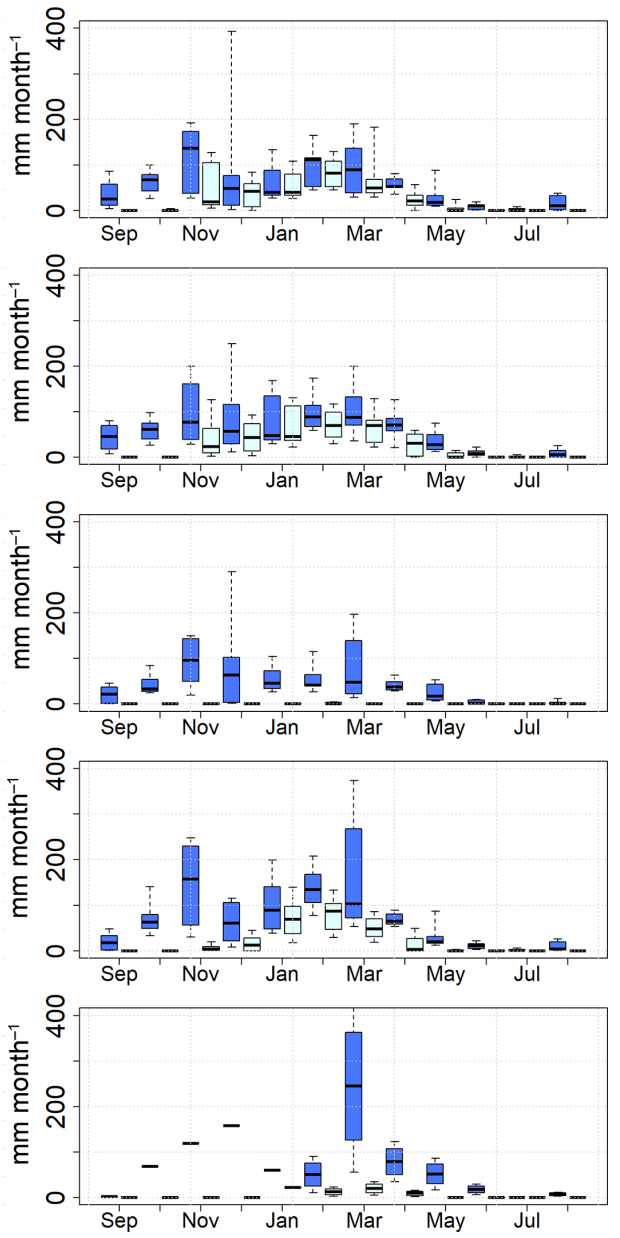

Figure 7. Precipitation and snowfall in the weather stations of the Guadalfeo Network in Sierra Nevada (Spain). Column (a) shows annual precipitation and snowfall at each station during the 2004-2016 period. Column (b) shows mean monthly precipitation and snowfall at each station during the study period; box plots show the mean values (black line), interval range and the 10th and 90th percentiles (whiskers) of each sample (series duration in Fig. 3).

monthly basis (Pérez-Palazón et al., 2018). The snowfallrainfall classification is calculated on an hourly basis by using a threshold temperature of $0^{\circ} \mathrm{C}$ at each station.

The altitudinal gradient of precipitation does not directly correlate with that associated with snowfall. PG1 and PG2 show the highest values of annual snowfall, with similar monthly patterns and volumes; PG4 records higher precipitation amounts but results in lower snowfall values, especially during autumn. The short recording period of PG5 prevents any further analysis; as expected due to the location on the northern face of Sierra Nevada, the recorded annual precipitation is higher than its southern sister stations, but its occurrence mainly during the late winter-early spring decreased the amount of snowfall during this particular year. PG3 is not located in a snow domain area.
The snow season usually extends from November to April, with some occurrences of sometimes heavy snowfall in MayJune at the highest stations.

The monitoring of the incoming radiation components led to the validation of the conclusions of the first attempt to model the snowpack accumulation-ablation cycles in the Refugio Poqueira experimental site (Herrero et al., 2009). This work estimated the sublimation rates from an energy balance model, but no direct observations were available at that time. From the incoming longwave radiation measurements at station PG2, an empirical expression for the atmospheric emissivity was derived (Herrero and Polo, 2012), and different field campaigns were done to measure and validate the estimated snowmelt-evaposublimation fluxes on a seasonal and annual scales at this experimental site (Herrero and Polo, 2016). The results highlight the importance of the evaposublimation fraction in mountain areas in semiarid re- 
gions and the need for considering this component in the water balance in these catchments to avoid overestimations of the contribution of the snowpack to the water volumes in aquifers and reservoirs from the observed snow cover area in the headwater zone.

The fractional snow cover and snow depth time series from the time-lapse camera imagery constitute key information for studying the microscale effects on the snowpack ablation dynamics and the patchy pattern evolution. These effects need to be quantified in the distributed modelling of snow to prevent both over- and underestimations of the snow water equivalent in the snowpack when the energy and mass balance equations are solved over the cell area of a gridded representation of the snow cover area. The analysis of both the dynamics and timing during the season of the accumulation and ablation phases in the Refugio Poqueira experimental site (S2-C2 and PG2 in Fig. 2) led to the retrieval of different depletion curves, which were associated with different antecedent conditions during the snow season; therefore, a decision tree could be applied in the workflow of the model to better approximate the actual fractional snow cover and snow depth on a pixel basis (Pimentel et al., 2017c). Figure 8 shows the dimensionless version of these depletion curves, with a single accumulation pattern but four potential patterns depending on the antecedent conditions during the snow season. Curve 0 describes the accumulation phase, which is initially very fast and slows down to close to $50 \%$ of the maximum snow cover area and reaches a maximum snow depth threshold, beyond which the area is completely covered. Curve 1 to 4 describe the ablation phase under different conditions: large amounts of snow from long accumulation phases, with a very compact state and a high level of metamorphism (Curve 1) or from short accumulation and nonpersistent phases (Curve 2); lower amounts of snow accumulated during autumn-winter with longer snowmelt phases (Curve 3) or spring, with quick ablation due to the warmer conditions (Curve 4).

Finally, the data set from the cameras covering the hillslope-scale scenes ( $\mathrm{C} 1$ and $\mathrm{C} 3$ ) constitutes valuable ground-truth information for the remote sensing community working on the retrieval of snow products. Figure 9 shows the analysis of the performance of two different algorithms for quantifying the snow cover area on large areas from Landsat TM images (Pimentel et al., 2017a) by means of their comparison with the snow maps of the $2 \mathrm{~km}^{2}$ scene from $\mathrm{C} 1$ images (Fig. 3 and Table 2). In addition to the expected conclusion about a fractional approach being more accurate than a binary algorithm for snow cover area estimations, it must be highlighted that the data allowed the quantification of the over- and underestimation level through each approach for different states of the snowpack, together with the identification of states for which both algorithms provided similar results or failed in achieving an adequate approximation. Despite the current availability of high spatial resolution satellite data sources, such as the Sentinel missions, these can-

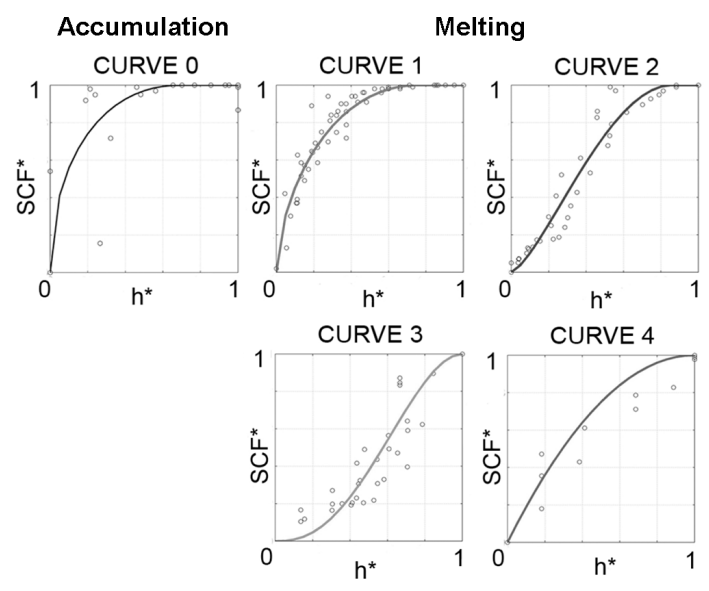

Figure 8. Snow depletion curves on a cell basis retrieved from the data from the images of the time-lapse camera C2 at Refugio Poqueira in the Guadalfeo Network. Different accumulation (Curve 0) and ablation (Curve 1-4) patterns relate the dimensionless fractional snow cover $\left(\mathrm{SCF}^{*}\right)$ and snow depth $\left(h^{*}\right)$ at the $30 \mathrm{~m} \times 30 \mathrm{~m}$ scene during the snow season (1 November-31 May) from data during the 2009-2013 period. Adapted from Pimentel et al. (2017b).

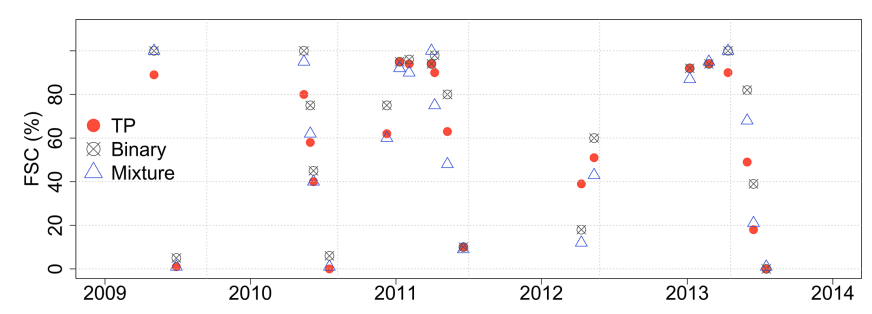

Figure 9. Comparison between the observed fractional snow cover (FSC) evolution (2009-2014) in the camera C2 scene area from the Guadalfeo Network (TP, red dots) and the estimated value from two different retrieval algorithms based on Landsat TM data: a binary approach (snow-no snow) and a fractional approach from a spectral mixture algorithm (FSC in every pixel of the satellite image). Adapted from Pimentel et al. (2017a).

not provide long time series to analyse trends and changes in the snow regime, Landsat data being the most adequate data source in terms of long series and high spatial resolution in these highly heterogeneous snow pattern domains.

\section{Data availability}

All data presented in this work are available from different open-access sources. The weather stations in the Guadalfeo Network are maintained by the Fluvial Dynamics and Hydrology Research Group of the Andalusian Institute for Earth System Research (University of Cordoba), and the data sets are included and updated in the CLIMA public database of the Andalusian regional government. The meteorological hourly and daily data sets are provided as .txt files 
at https://doi.org/10.1594/PANGAEA.895236 (Polo et al., 2018).

The fractional snow cover and snow depth data set at Refugio Poqueira site (camera C2) can be downloaded from https://doi.org/10.1594/PANGAEA.871706 (Pimentel et al., 2017b); the snow cover maps for selected dates from 2011 (camera C1) are available from https://doi.org/10.1594/PANGAEA.898374 (Polo et al., 2019).

The updated meteorological records and quasi-real-time representation of the snow cover area in the Guadalfeo Experimental Catchment can also be accessed at http://www. uco.es/dfh/snowmed/ (last access: 30 August 2018; in Spanish).

\section{Final summary}

This work presents the Guadalfeo Monitoring Network in the Guadalfeo Experimental Catchment, Sierra Nevada (southern Spain), an alpine headwater area in a semiarid region with steep topography and sea-climate influence. The data sets include both meteorological time series from the weather stations in the network and fractional snow cover area and snow depth time series retrieved from imagery from timelapse cameras at selected points in the network. Different examples of research applications are also included to highlight the value of these research monitoring networks to acquire high-resolution and high-quality data sets, absolutely essential for capturing the significant scales of the snowpack regime in these highly heterogeneous areas.

The data shown are representative of the main issues characterizing high mountain climate in semiarid catchments and provided the research team with the basis for further understanding the major drivers of the snow accumulationablation patterns, the interaction of the microrelief or the partitioning of snowmelt and evaposublimation under different predominant conditions. The significant gradients of the snowpack regime found in Sierra Nevada both in the northsouth and west-east axes still pose questions to be answered in a context of increasing variability of the climatic drivers in these regions, where the associated impacts, not only on water availability during the dry season and years, but also on the operational design and exploitation of the water storage systems (reservoirs, aquifers, etc.), constitute an issue of priority from both the scientific and technical point of view.

The Guadalfeo Network is a live structure that keeps on expanding, funded by different research projects and specific actions of infrastructure investment and maintaining. A new weather station has recently started recording data at $2500 \mathrm{~m}$ a.s.l. on the northern face of Sierra Nevada, and the Refugio Poqueira experimental site (PG2) has been equipped with additional sensors (snow water equivalent measurement and a 4-component pyrgeometer) to gain deeper understanding of snow processes in this area. The possibility of shar- ing these data and discussing the outcomes of this research work with the snow community in INARCH (International Network for Alpine Research Catchment Hydrology) opens a collaborative framework for new and wider opportunities to answer relevant scientific questions and share scientific knowledge from different mountain regions in the world. Moreover, the availability of the information from openaccess platforms offers other application and research fields validated data sets in research branches such as remote sensing of the snowpack but also ecology, water quality or fire risks, among others, widening the international community of potential users and multidisciplinary interactions.

Author contributions. MJP and JH designed the Guadalfeo Monitoring Network (GMN) and coordinate it. JH is responsible for installing and maintaining the GMN. RP, MJPP and JH processed GMN data and produced the associated data sets presented in this paper. MJP prepared the manuscript with contributions from all authors. RP prepared the final figures.

Competing interests. The authors declare that they have no conflict of interest.

Special issue statement. This article is part of the special issue "Hydrometeorological data from mountain and alpine research catchments". It is not associated with a conference.

Acknowledgements. The Guadalfeo Monitoring Network (GMN) is the extension of the initial weather station at Refugio Poqueira in 2004 within the framework of the Guadalfeo Project (Andalusian Regional Government), coordinated by Miguel A. Losada from the Andalusian Institute for Earth System Research at the University of Granada, whose continuous support and inspiration made the creation of the Fluvial Dynamics and Hydrology research group in 2009 possible, which has been responsible for the GMN ever since. The authors thank both J. Ignacio López-Moreno and Simon Gascoin for their comments and contributions to the final version of this paper.

This study was supported by the following research projects funded by the Spanish Ministry of Economy and Development (MINECO): Research Project CGL 2014-58508R, "Global monitoring system for snow areas in Mediterranean regions: trends analysis and implications for water resource management in Sierra Nevada", and Research Project CGL 2011-25632, "Snow dynamics in Mediterranean regions and its modelling at different scales. Implication for water management". This study was also co-financed by the European Regional Development Fund (ERFD). The annual editions of the Research Program of the University of Cordoba also contributed to the instrumentation renewal and maintenance.

The authors want to acknowledge the International Network for Alpine Research Catchment Hydrology (INARCH) for the opportunity to share individual research experiences and data. The continuous support of the Natural and National Park of Sierra Nevada has 
also been determinant for the development of this line of research since 2002.

Review statement. This paper was edited by John Pomeroy and reviewed by Simon Gascoin and J. Ignacio López-Moreno.

\section{References}

Aguilar, C. and Polo, M. J.: Generating reference evapotranspiration surfaces from the Hargreaves equation at watershed scale, Hydrol. Earth Syst. Sci., 15, 2495-2508, https://doi.org/10.5194/hess-15-2495-2011, 2011.

Aguilar, C. and Polo, M. J.: Assessing minimum environmental flows in nonpermanent rivers: The choice of thresholds, Environ. Modell. Softw., 79, 120-134, https://doi.org/10.1016/j.envsoft.2016.02.003, 2016.

Aguilar, C., Herrero, J., and Polo, M. J.: Topographic effects on solar radiation distribution in mountainous watersheds and their influence on reference evapotranspiration estimates at watershed scale, Hydrol. Earth Syst. Sci., 14, 2479-2494, https://doi.org/10.5194/hess-14-2479-2010, 2010.

Algarra, J. A., Cariñanos, P., Herrero, J., Delgado-Capel, M., Ramos-Lorente, M. M., and Díaz de la Guardia, C.: Tracking Montane Mediterranean grasslands: Analysis of the effects of snow with other related hydro-meteorological variables and landuse change on pollen emissions, Sci. Total Environ., 649, 889901, https://doi.org/10.1016/j.scitotenv.2018.08.311, 2019.

Anderson, R. S., Jiménez-Moreno, G., Carrión, J. S., and Pérez-Martínez, C.: Postglacial history of alpine vegetation, fire, and climate from Laguna de Río Seco, Sierra Nevada, southern Spain, Quaternary Sci. Rev., 30, 1615-1629, https://doi.org/10.1016/j.quascirev.2011.03.005, 2011.

Anderton, S. P., White, S. M., and Alvera, B.: Evaluation of spatial variability in snow water equivalent for a high mountain catchment, Hydrol. Process., 18, 435-453, https://doi.org/10.1002/hyp.1319, 2004.

Andrew, J. and Sauquet, E.: Climate Change Impacts and Water Management Adaptation in Two Mediterranean-Climate Watersheds: Learning from the Durance and Sacramento Rivers, Water, 9, 126, https://doi.org/10.3390/w9020126, 2017.

Barnett, T. P., Adam, J. C., and Lettenmaier, D. P.: Potential impacts of a warming climate on water availability in snow-dominated regions, Nature, 438, 303-309, https://doi.org/10.1038/nature04141, 2005.

Blanca, G.: Flora amenazada y endémica de Sierra Nevada, Consejería de Medio Ambiente, Junta de Andalucía, Granada, Spain, 2002.

Egüen, M., Aguilar, C., Solari, S., and Losada, M. A.: Non-stationary rainfall and natural flows modeling at the watershed scale, J. Hydrol., 538, 767-782, https://doi.org/10.1016/j.jhydrol.2016.04.061, 2016.

Ergon, Å., Seddaiu, G., Korhonen, P., Virkajärvi, P., Bellocchi, G., Jørgensen, M., Østrem, L., Reheul, D., and Volaire, F.: How can forage production in Nordic and Mediterranean Europe adapt to the challenges and opportunities arising from climate change?, Eur. J. Agron., 92, 97-106, https://doi.org/10.1016/j.eja.2017.09.016, 2018.
Favier, V., Falvey, M., Rabatel, A., Praderio, E., and López, D.: Interpreting discrepancies between discharge and precipitation in high-altitude area of Chile's Norte Chico region $\left(26-32^{\circ} \mathrm{S}\right)$, Water Resour. Res., 45, W02424, https://doi.org/10.1029/2008WR006802, 2009.

Fayad, A., Gascoin, S., Faour, G., López-Moreno, J. I., Drapeau, L., Le Page, M., and Escadafal, R.: Snow hydrology in Mediterranean mountain regions: A review, J. Hydrol., 551, 374-396, 2017.

Fiume, E. L.: The Mathematical Structure of Raster Graphics, Academic Press, London, UK, 2014.

Foley, J. D.: Computer Graphics: Principles and Practice, AddisonWesley Professional, Boston, MA, USA, 1996.

Gómez-Beas, R., Moñino, A., and Polo, M. J.: Development of a management tool for reservoirs in Mediterranean environments based on uncertainty analysis, Nat. Hazards Earth Syst. Sci., 12, 1789-1797, https://doi.org/10.5194/nhess-12-1789-2012, 2012.

Gómez-Giráldez, P. J., Aguilar, C., and Polo, M. J.: Natural vegetation covers as indicators of the soil water content in a semiarid mountainous watershed, Ecol. Indic., 46, 524-535, https://doi.org/10.1016/j.ecolind.2014.06.024, 2014.

Herrero, J. and Polo, M. J.: Parameterization of atmospheric longwave emissivity in a mountainous site for all sky conditions, Hydrol. Earth Syst. Sci., 16, 3139-3147, https://doi.org/10.5194/hess-16-3139-2012, 2012.

Herrero, J. and Polo, M. J.: Evaposublimation from the snow in the Mediterranean mountains of Sierra Nevada (Spain), The Cryosphere, 10, 2981-2998, https://doi.org/10.5194/tc-10-29812016, 2016.

Herrero, J., Polo, M. J., Moñino, A., and Losada, M. A.: An energy balance snowmelt model in a Mediterranean site, J. Hydrol., 371, 98-107, https://doi.org/10.1016/j.jhydrol.2009.03.021, 2009.

Herrero, J., Polo, M. J., and Losada, M. A.: Snow evolution in Sierra Nevada (Spain) from an energy balance model validated with Landsat TM data, edited by: Neale, C. M. U. and Maltese, A., 817403, https://doi.org/10.1117/12.898270, 2011.

Heywood, V. H.: The Mediterranean flora in the context of world diversity, Ecología Mediterránea, 21, 11-18, 1995.

Liston, G. E. and Hiemstra, C. A.: The Changing Cryosphere: PanArctic Snow Trends (1979-2009), J. Climate, 24, 5691-5712, https://doi.org/10.1175/JCLI-D-11-00081.1, 2011.

López-Moreno, J. I., Goyette, S., and Beniston, M.: Impact of climate change on snowpack in the Pyrenees: Horizontal spatial variability and vertical gradients, J. Hydrol., 374, 384-396, 2009.

López-Moreno, J. I., Gascoin, S., Herrero, J., Sproles, E. A., Pons, M., Alonso-González, E., Hanich, L., Boudhar, A., Musselman, K. N., Molotch, N. P., Sickman, J., and Pomeroy, J.: Different sensitivities of snowpacks to warming in Mediterranean climate mountain areas, Environ. Res. Lett., 12, 074006, https://doi.org/10.1088/1748-9326/aa70cb, 2017.

MacQueen, J. B.: Some methods for classification and analysis of multivariate observations, Proceeding, Fifth Symposium on Math, Statistics, and Probability, 21 June-18 July 1965, Berkeley, CA, USA, 281-297, 1967.

Mankin, J. S. and Diffenbaugh, N. S.: Influence of temperature and precipitation variability on near-term snow trends, Clim. Dynam., 45, 1099-1116, https://doi.org/10.1007/s00382-014-23574, 2015 . 
Marchane, A., Jarlan, L., Hanich, L., Boudhar, A., Gascoin, S., Tavernier, A., Filali, N., le Page, M., Hagolle, O., and Berjamy, B.: Assessment of daily MODIS snow cover products to monitor snow cover dynamics over the Moroccan Atlas mountain range, Remote Sens. Environ., 160, 72-86, 2015.

Marty, C., Schlögl, S., Bavay, M., and Lehning, M.: How much can we save? Impact of different emission scenarios on future snow cover in the Alps, The Cryosphere, 11, 517-529, https://doi.org/10.5194/tc-11-517-2017, 2017.

Mernild, S. H., Liston, G. E., Hiemstra, C. A., Malmros, J. K., Yde, J. C., and McPhee, J.: The Andes Cordillera. Part I: snow distribution, properties, and trends (1979-2014), Int. J. Climatol., 37, 1680-1698, https://doi.org/10.1002/joc.4804, 2017.

Mhawej, M., Faour, G., Fayad, A., and Shaban, A.: Towards an enhanced method to map snow cover areas and derive snow-water equivalent in Lebanon, J. Hydrol., 513, 274-282, 2014.

Millares, A., Polo, M. J., and Losada, M. A.: The hydrological response of baseflow in fractured mountain areas, Hydrol. Earth Syst. Sci., 13, 1261-1271, https://doi.org/10.5194/hess-13-12612009, 2009.

Millares, A., Polo, M. J., Moñino, A., Herrero, J., and Losada, M. A.: Bedload dynamics and associated snowmelt influence in mountainous and semiarid alluvial rivers, Geomorphology, 206, 330-342, https://doi.org/10.1016/j.geomorph.2013.09.038, 2014.

Molotch, N. and Meromy, L.: Physiographic and climatic controls on snow cover persistence in the Sierra Nevada Mountains, Hydrol. Process, 28, 4573-4586, 2014.

Musselman, K. N, Clark, M., Liu, C., Ikeda, K., and Rasmussen, R.: Slower snowmelt in a warmer world, Nat. Clim. Change, 7, 214-119, https://doi.org/10.1038/nclimate3225, 2017.

NOAA: http://www.swpc.noaa.gov/, last access: 8 September 2016.

Pérez-Palazón, M. J., Pimentel, R., Herrero, J., Aguilar, C., Perales, J. M., and Polo, M. J.: Extreme values of snow-related variables in Mediterranean regions: trends and long-term forecasting in Sierra Nevada (Spain), Proc. IAHS, 369, 157-162, https://doi.org/10.5194/piahs-369-157-2015, 2015.

Pérez-Palazón, M. J., Pimentel, R., and Polo, M. J.: Climate Trends Impact on the Snowfall Regime in Mediterranean Mountain Areas: Future Scenario Assessment in Sierra Nevada (Spain), Water, 10, 720, https://doi.org/10.3390/w10060720, 2018.

Pimentel, R., Herrero, J., Zeng, Y., Su, Z., and Polo, M. J.: Study of Snow Dynamics at Subgrid Scale in Semiarid Environments Combining Terrestrial Photography and Data Assimilation Techniques, J. Hydrometeorol., 16, 563-578, https://doi.org/10.1175/JHM-D-14-0046.1, 2015.
Pimentel, R., Herrero, J., and Polo, M. J.: Quantifying Snow Cover Distribution in Semiarid Regions Combining Satellite and Terrestrial Imagery, Remote Sensing, 9, 995, https://doi.org/10.3390/rs9100995, 2017a.

Pimentel, R., Herrero, J., and Polo, M. J.: Snow Cover Fraction (SCF) and snow depth obtained using terrestrial photography (2009-2013) in the control area Refugio Poqueira (Sierra Nevada, Spain), PANGAEA, https://doi.org/10.1594/PANGAEA.871706, 2017b.

Pimentel, R., Herrero, J., and Polo, M. J.: Subgrid parameterization of snow distribution at a Mediterranean site using terrestrial photography, Hydrol. Earth Syst. Sci., 21, 805-820, https://doi.org/10.5194/hess-21-805-2017, 2017c.

Polo, M. J., Herrero, J., Pimentel, R., and PérezPalazón, M. J.: Meteorology data of Guadalfeo Monitoring Network (Sierra Nevada, Spain), PANGAEA, https://doi.org/10.1594/PANGAEA.895236, 2018.

Polo, M. J., Herrero, J., Pimentel, R., and Pérez-Palazón, M. J.: Snow cover maps (C1) of Guadalfeo Monitoring Network (Sierra Nevada, Spain), PANGAEA, https://doi.org/10.1594/PANGAEA.898374, 2019.

Rizzi, J., Nilsen, I. B., Stagge, J. H., Gisnås, K., and Tallaksen, L. M.: Five decades of warming: impacts on snow cover in Norway, Hydrol. Res., 49, 670-688, https://doi.org/10.2166/nh.2017.051, 2018.

Senatore, A., Mendicino, G., Smiatek, G., and Kunstmann, H.: Regional climate change projections and hydrological impact analysis for a Mediterranean basin in Southern Italy, J. Hydrol., 399, 70-92, 2011.

Valdés-Pineda, R., Pizarro, R., García-Chevesich, P., Valdés, J. B., Olivares, C., Vera, M., Balocchi, F., Pérez, F., Vallejos, C., Fuentes, R., Abarza, A., and Helwig, B.: Water governance in Chile: Availability, management and climate change, J. Hydrol., 519, 2538-2567, https://doi.org/10.1016/j.jhydrol.2014.04.016, 2014.

Verbyla, D., Hegel, T., Nolin, A., van de Kerk, M., Kurkowski, T., Prugh, L., Verbyla, D., Hegel, T., Nolin, A. W., van de Kerk, M., Kurkowski, T. A., and Prugh, L. R.: Remote Sensing of 2000 2016 Alpine Spring Snowline Elevation in Dall Sheep Mountain Ranges of Alaska and Western Canada, Remote Sensing, 9, 1157, https://doi.org/10.3390/rs9111157, 2017. 